\title{
Pattern Reproduction Possibilities and the Alpha and Omega of Tibetan Printing
}

\author{
T. H. Barrett
}

When is a printing revolution not a revolution? When it takes place in East Asia. Or so we might guess from current writing on the rise of printing in China, where even those disposed to use the word 'renaissance' freely with regard to changes there prefer not to conjoin the ideas of printing and revolution, quite explicitly (Goody 2010, 23-4). ${ }^{1}$ Yet in a recent monograph on an eleventh-century Chinese poet, Yugen Wang points to verifiable changes in thinking about literary practice that can only be associated with the introduction of printing. The amplification of the number of texts, the accumulation of knowledge, the standardization of texts, even the 'Montaigne effect' of making visible the relativity of knowledge, at least at that basic textual level, are all there in his discussion (Wang 2011, 174-82). Some would further see the rise of the profession of medicine as an elite career based on published, standardized medical classics as attributable to the same technological innovation (Hansen 2011, 220-21, makes this point more concisely and cogently than the work she reviews). Only the constitution of communities through print as posited by Benedict Anderson seems absent, perhaps because the world of letters in those times was in its boundaries as clearly delineated as it had been in earlier centuries, even if its circumference had expanded. Despite this, printing as a vigorous commercial phenomenon is, in the view of some experts at least, a product of the sixteenth century in China. On this understanding the little revolution of the tenth and eleventh centuries seems by the fourteenth to have lost its vigour, and to have languished until some new impetus propelled an already familiar technology to new heights of significance (McDermott 2006, 48-49).

So, then, was the rise of Tibetan printing a big revolution or a small one? The answer is by no means simple. This is because to some extent an assessment of the Chinese example, and for that matter the Japanese example too, depends after all upon where one draws the base line. In Europe, printing appears as it

1 The notion of renaissance as applicable to China is much better established: Peter Burke, following Toynbee, was using it as early as 1964: see Burke 1964, 141.

(C) T. H. BARRETT, 2016 | DOI 10.1163/9789004316256_027

This is an open access chapter distributed under the terms of the Creative Commons Attribution-

Noncommercial 3.0 Unported (CC-BY-NC 3.0) License. 
were out of nowhere, as a genuinely new technology, though as we shall see the exact degree of its novelty can perhaps be overstated. But this was certainly not the case in East Asia, quite indubitably not in China or Japan, nor yet, as I would argue, in Tibet either. This may seem a bold assertion from an outsider to Tibetan studies, but it relates as much to a broad view of the nature of printing as a variant form of a class of fairly widespread technologies as to any specific knowledge of the Tibetan case.

To be frank, the following remarks have been put together on the basis of an almost total absence of knowledge concerning Tibet, and even less about printing there, beyond what has been gleaned in passing from a primary interest in China. Thus an interest in Dunhuang as a source of printed materials has at least alerted me to what appears to be the earliest printed material in Tibetan, namely P. tib, 4216, a printed spell that some have assumed was produced there during the Tibetan occupation - that is, rather earlier than any other printed material from Dunhuang of demonstrably local origin (Cohen and Monnet 1992, 59. See Rong 2004, 62, for Dunhuang printing in Chinese in the tenth century). The assumption may in fact be incorrect, in that Tibetan was still clearly used in Dunhuang after the reassertion of Chinese control into the tenth century, especially in connection with Buddhist materials of this type (van Schaik and Galambos 2012, 29-34). If in any case this is the beginning of the story of Tibetan printing, when does it end, at least in the sense of linking with the wider, global printing community? The literal invasion of Tibet by the West must date to Sir Francis Younghusband's (1863-1942) expedition of 1904, when we read: "Painted clay images of the Buddha were smashed open, but to the disappointment of the marauders there was nothing inside them but block-printed mantras" (French 1994, 229 - despite the term mantra, the same material as appears at Dunhuang is indicated). ${ }^{2}$ Such vandalism was of course nothing new to Western imperialism - similar treasure-seeking expedients during the bloody reprisals for the Boxer Uprising had already contributed some unusual materials to Chinese printing history (Carter 1955, 111-12). In fact the assumption must be that the highly durable technology encountered by Younghusband's troops here came originally from China, and certainly the Blue Annals suggest that, at a somewhat later date, printed single sheets combining

2 For the meaning of the practice of placing texts inside images, see Barrett 2005, 61. If one discounts the Younghusband episode, then perhaps Tibet was drawn into the wider world of printing rather later, when the French Orientalist André Migot arrived in sDe dge in 1947 with some specific reprinting request, to the astonished monks there, as described in his book Tibetan Marches (1956, Chapter Xxv). 
image and text were imported from there into Tibet (Roerich 1949, 911). ${ }^{3}$ The point that should be noted, however, is that once established, the production and circulation of single sheets of woodblock bearing words or images of power persisted for something like a millennium.

So, whatever the importance or even the revolutionary nature of the arrival of the entire printed book, in Tibet as is other parts of Asia, if not elsewhere, this took place against the background of forms of printing already well established and destined to endure much longer. Even these products, for their part, need to be seen against a wider background of even simpler or simply different modes of pattern reproduction. The following remarks - which are far from exhaustive - are designed to sketch this wider background to printing, using examples that are in part common knowledge, in part drawn from an interest in Chinese pattern reproduction that I have developed over a number of years. And in using the words 'simpler or simply different' I mean to acknowledge thereby that the production of a complex object such as a printed book, though obviously a more demanding task than the production of a single sheet, does not necessarily rest at the apex of a hierarchy of possibilities. Pattern reproduction is too diverse to construct such a pyramid.

After all, the transfer of an image to a new surface is something that takes place in nature without human intervention. Allegedly the inventor of lithography, Alois Senefelder, was inspired by the print of a plant left on a stone - or so we are informed according to the poem 'A Sprig of Moss' by William McGonagall (1825-1902), the finest (because to my knowledge the only) and also by far, far the worst literary tribute to this technology (McGonagall 1934, 214-16). ${ }^{4} \mathrm{We}$ should in passing no doubt note that the twentieth-century Scottish publishers of McGonagall's writings in book form boast that their firm typeset the single sheet handbills the great man originally used to circulate his compositions, for the history of the unbound, single folio print was by no means extinct in Britain in Younghusband's youth, even if we do not reflect much on this today. By using the word 'pattern', however, I wish to focus on repeated transfers, though here too nature has played its part. The Chinese writing system, after all, is said in traditional accounts to owe its origins to human contemplation of the tracks of birds and beasts - something perhaps not without significance for the history of printing either. ${ }^{5}$

3 For the story depicted, see Barrett 2012, pp. 47-8.

4 The poet's work first appeared in broadsheet from David Winter \& Son, Dundee.

5 For a video summary of an unpublished paper on this topic, see www.sms.cam.ac.uk/ media/1259713. 
Certainly man seems to have learned from the animals in this matter very early on, to judge from the hand prints, usually it seems made by women, that feature across the world in cave art. The two techniques used to create these already exemplify the two main principles involved in pattern reproduction, namely blocking and striking. In the former technique, the hand was placed against the cave wall, and red ochre powder blown or otherwise applied around it, creating a stencil effect where the hand is outlined by the pigment. The use by cave women of red powder in particular in such contexts is echoed by the use of red powder in Chinese medieval pounces - a form of stencil discussed below - in a technique that apparently continues into the present day (Fraser 2004, 270, n. 72). Alternatively, the hand could be covered in pigment and struck against the rock to impress a coloured shape. Blocking usually involves a soft material being applied to a harder one, whereas striking involves a harder material applied to a softer one; in this case, however, the hard hand transfers the soft pigment to another hard surface, like ink to a page. More typical perhaps of striking or impressing would be the cord pottery of Japan 12,00o years ago, where patterns were imposed on damp clay during ceramic manufacture. As a form of pattern reproduction, impressing clay, especially by stamping, has had an immensely long history (Ledderose 2000, 160, cites Chinese research dating stamping back to the Neolithic). Reproducing some Han examples of stamped tomb bricks, the contemporary ceramicist Grayson Perry writes "The Chinese clay workers used exactly the same techniques I use, over 2200 years later" (Perry 2011, 88; the Han technique is explained in Čapek 1962, 49).

In the case of cord marking, however, a flat surface is not required. Pattern reproduction need not be two-dimensional but may be extended into three, especially when soft meeting hard involves the introduction of soft material into a mould for subsequent fixing. A mould - so important in the context of metallurgy - can be seen as a three dimensional stencil, blocking the natural flow of a soft or molten substance so that it takes the form of the harder substance surrounding it. In Bronze Age China, three thousand years ago, the use of moulds achieved great sophistication, even being employed to cast inscriptions on bronze vessels, though close examination shows that for each casting of a character (inscriptions often appear in duplicate on a vessel) fresh moulds were used de novo - the idea of multiplication does not initially seem to be present at all, though it did arrive a few centuries later (Ledderose 2000, 40-41; on pp. 41-8 he goes on, however, to explain the later 'cloning' and multiple manufacture of whole vessels). There does exist one example where the inscription is moulded character by character, so that had the moulds been used repeatedly, this would already have constituted a form of movable type (Ledderose 2000, 156). 
But to revert to Japan, note also that the cord marks, as far as we know, do not convey meaning or represent anything other than pattern in the abstract, unlike the handprints - though this cannot be entirely certain, since we know that meanings can be applied by their users to non-representational patterns in beads and the like. In general, though, pattern can vary from the purely decorative to the multiple replications of meaningful images, the standardizing effect of which could have been felt long before modernity - that is, even in the ancient world. Moulds for the manufacture of small terracotta figures of gods still survive from twenty-four centuries ago. Perhaps by reason of the scale and breadth of distribution achieved, they were not capable of imposing uniformity on conceptions of iconography, but they could have been influential even so (see image no. 3 in Nicholls 1978, 7-8). For unlike a cave wall, such figurines were portable, and unlike cord pottery that was at first presumably created for immediate use, the creators of these small figurines must have made them in order to be marketed.

But it was surely the invention of coinage around $600 \mathrm{CE}$ that had the deepest early impact of this type. In the Mediterranean world the coinage was struck, using dies, a technology already present - though using dies to strike clay, not metal - in the mysterious but certainly earlier Phaistos disk. There is eloquent testimony to the way in which die struck coins carried standardizing messages far and wide in the New Testament: "Render unto Caesar that which is Caesar's", says Jesus in the Gospels, on the basis of the 'image and superscription' on a penny (Matthew 22:21; Mark 12:17; Luke 20:25). Chinese coinage dates back to the same period in the form of the moulded metal 'spade coins' and 'knife coins' that preceded later round forms, and though images were not used in East Asia, writing was usually included from very early on. This then would be a special case of the meaningful image, namely the linguistically meaningful image. And coins were certainly designed for portability, even if the space for a linguistic message was usually limited.

For a bigger image or longer message, a flat thin lightweight surface was clearly required, even if the multiple creation of lightweight metal objects bearing meaningful representations for widespread diffusion did find a place in the manufacture by stamping or casting of medieval pilgrim badges, a mass industry that has been seen as in a way antecedent to European printing (Parshall and Schoch 2005, 60-62). Grayson Perry likens their status as souvenir to that of the modern t-shirt: "My dad went to Canterbury and all I got was this lousy lead alloy badge!” (Perry 2011, 126).

Literally incorporating writing into clothing itself in a largely pre-literate age seems to have appealed less than the badge option. But abstract patterns were stamped onto textiles from much earlier on. Plates used by Chinese 
(or perhaps they were closer ethnically to Vietnamese) craftsmen to impose patterns on silk have been retrieved by archaeologists from the tomb of a second-century BCE king of the state of Nanyue, on the southern border of the Han empire, and this practice seems to have spread westward from China, resulting in more recent times in the widespread use of printed cottons (Lin 2012, 260-61). As is well known, the block printing of text and image on textiles designed not for wearing but for decorative or religious use would seem to stand also in the immediate background to the woodblock printing of Europe (Parshall and Schoch 2005, 21-3, 62-8). As well as stamps, textiles could be patterned by means of resists, including means of blocking not only by stencils but also by using wax resists in conjunction with dyes. I have suggested elsewhere that there was in the eighth century a certain degree of crossover between these techniques and the emerging technology of woodblock printing proper (Barrett 2001, 240-47).

Such developments, however, had to await the arrival of paper, though it is arguable that this invention retained close links conceptually with textiles. Paper clothing at any rate may be found as a substitute for textiles even in Song times among those with religious scruples against luxury (see Tsien Tsuinhsuin 1985, 112; Boretti 2004, 360). But when it was adopted as a writing material, it was very clearly the freedom of movement it allowed by comparison with bamboo strips that appealed, rather than its provision of a flat surface for stamping. The cursive calligraphic styles of the post-Han period can hardly be imagined without the availability of paper, but producing patterns on it by stamping or even - with one limited exception - imposing preformed words on it was not the most obvious response to the new product, compared to the enthusiastic Chinese response to its invitation to the untrammelled movement of the writing brush.

The limited exception involves its suitability as a surface on which to stamp what we translate as a 'seal'. Seals in the Western sense, as part of the security apparatus provided by enclosure of documents such as letters or other objects, were used in China (Richter 2013, 28-9). But the traditional Chinese 'chop' was more like a signature, authenticating a body of text or a painted image with which it shared a surface. One example of a seal on silk comes from a grave of the fourth century вСЕ (Ledderose 2000, 160). And if we look at the wording of seals, they share a feature with the other short pieces of text that had been from antiquity multiplied through striking or moulding. They are all, in short, captions, verbal labels performing a self-identifying function - indeed Chinese examples often include the phrase 'the seal of' such and such an official, just as Caesar's coins stated his identity as issuing authority. This is by no means to deny the great symbolic importance of Chinese seals, upon which much has 
been written, but simply to point out that by convention the amount of wording on them, as on a coin, was normally rather restricted. ${ }^{6}$

Paper did, however, make other technologies of facsimile reproduction possible that would have been much more expensive if not impossible had textiles been used. Take for example the reconstitution of a text in facsimile by means of tracing - a process of great value not simply in transmitting calligraphy but also later in Chinese history in creating an exact copy to transfer from an existing printed text to a new block. A surviving Tang example of ink traced calligraphy on transparent beeswax paper shows what could be achieved in the former case, and even if this material was scarcely a good medium for multiple reproductions it does show the copying resources at the Chinese printer's potential disposal (Richter 2013, 115, figure 3.1, from Liaoning Provincial Museum).

Tracing apart, moreover, another way in which paper could aid the exact creation of copies was through the creation of pounces. These are pieces of paper pierced through with small holes following a pre-existing ink outline of a figure or of some other pattern. The examples that survive from among the Dunhuang finds are iconographic: they are pinpricked sheets through which powder could be rubbed to create new outlines that a painter could follow in 'joining up the dots' to make a new icon in outline and proportion identical to the one that had served as the basis for the pounce, in essence a form of skeletal stencil. Such a technique could of course be applied on a variety of surfaces, typically in the creation of murals built up of multiple images of identical Buddha figures, but there are signs that pounces were also used in repeated textile designs (Fraser 2004, 102-108, gives an excellent summary and illustrations; note also her plate 14).

The question of multiplying images and texts in a Buddhist context is one to which we should return, but first mention should be made of one final means of reproduction made widely available through the spread of paper, even if not impossible with textiles, and that is the rubbing. This seems to be a distinctively Chinese technique, though in India impressions of relics were made in the seventh century using paste smeared on silk, as a part of a divination practice (Beal 2011, 59). Such corporeal impressions, however, also hark back to the hand-prints of cave women already mentioned, and may further connect with Western impressions of corporeal relics such as the famous Shroud of Turin, not to mention the corporeal impressions made by teeth in clay, used

6 For a good discussion of seals and authority extending from China to Inner Asia (though not Tibet), see Aubin 2010. That seals were usually at first rather brief even in religious contexts is suggested by the information in Drexler 1994, 10, but see also below on some more prolix seal messages. 
as authenticating seals in India but known to Chinese also (Barrett 2012, 16). Rubbings by contrast may conceivably have been valued for their contact with the original inscriptions, seen as prestigious objects, but technologically are in some respects much closer to printing in reverse, in that a hard surface bearing a pattern - usually a linguistically meaningful pattern in the form of an incised inscription - is not used to strike the paper, but rather the paper, as a semielastic substance, is introduced to the hard pattern and pressed into its shape, so that when the remainder of the surface is inked, the portions pressed into the inscription are left white. ${ }^{7}$

To create a rubbing from an inscription takes a little time, but not unduly long, though the production is of course far less instantaneous than the creation of an impression by stamping (see Barrett 2011, 205). The creation of the stamp itself in the form of a Chinese seal, even if made out of a hard stone rather than wood, might by contrast take a certain amount of effort, but apparently even a beginner might not find the creation of a short message unduly difficult, and even surprisingly quick. ${ }^{8}$ But to talk of such matters implies a shift from an artisan's concern with accuracy of reproduction alone to a quest not simply for multiple replications but also for rapid and high volume production too. This would seem to imply the existence of a market, but the market for most of the patterned objects we have considered so far cannot have involved simple economics, in that none of them can be considered essentials - a pilgrim badge serves no immediate practical function, any more than does a terracotta statuette. Cultural factors determine the market for mass art even more than for luxury art, when people have less money. How important is it to be known as a pilgrim, or as the possessor in terracotta of what a rich man might have in marble and twenty times the size?

And this is just to assume a merely social role for the multiply created copy. It might also have a personal one, as a memento or even an object of devotion. Or its very creation might serve some religious function - not a factor that we think about much in the European context, but essential to understanding the use of pattern transfer in the Buddhist world, and especially the Mahāyāna Buddhist world. It has long been recognised that the acquisition of merit,

7 The most useful monograph on rubbings, Starr 2008, carries a good account of the apparent origins of rubbings by the sixth century and the existence of early examples from 654 onwards (pp. 3-24), besides exhaustive accounts of rubbing techniques, including (pp. 1447) the form of rubbing used in Europe to copy monumental brasses in churches. The bilingual work by Liu Wing-fong (1986) is also handy.

8 Robert Van Gulik $(1958,437)$ records his experience of learning to create seals; one he eventually completed in "about an hour" (sic!). 
through the multiplication of texts like the Diamond Sutra, provided an important religious impetus towards the adoption of printing (Carter 1955, 56-7). But recent scholarship has gone further to uncover the reasons for this, in that the form of Buddhism that came to be called Mahāyāna, 'The Greater Vehicle', as this polemical self-designation itself hints, was precisely very far in its early days from commanding numerically significant support amongst adherents of Buddhism, and so from its marginal position had to rely on writing to spread its message in opposition to the mainstream of Buddhist literature, which clearly had oral origins and was sustained by collective memorization by the established Buddhist clergy (for a good summary of recent rethinking on this issue, see Williams 2009, 1-44). To the advocates of new ideas, a book was just as important as a relic of the Buddha - in fact, it was a relic of the Buddha. For had he not said that whoever saw his words, saw him? (Cf. Barrett 2008, 45.)

Perhaps precisely because the message of the Mahāyāna goes back to outsiders on the fringes of the main Buddhist community, one gets a certain sense in the literature of the movement of being addressed through a megaphone. Volumes are ramped up rhetorically at every point, in the sense that there is more of everything - more Buddhas, more world systems, and more exhortations to propagate the message. Multiplication becomes the norm, hence for example the establishment of the 'Thousand Buddha' pattern known to art historians in China - and the need for mechanical aids like pounces to help create so many identical images. And in particular these images - which, like texts, count as relics also - amplified the material presence of the Buddha. The quickest way to multiply images and set them in appropriate reliquaries stūpas, that is - was to mould the tiny shrines out of clay and include a tiny image or saying of the Buddha or both. This was most certainly a merit producing religious act in itself, so this makes the very moulds themselves, the matrices from which the tiny instantiations of sanctity emerged, into sacred objects, as Grayson Perry again notices (Perry 2011, 140, where Tibetan moulds are illustrated; cf. Barrett 2012, 55-6, for some much earlier evidence.). I do not believe that this ever happened in Europe with moulds for sacred images or indeed woodblocks for religious prints, which only served as means to an end, quite unlike the woodblocks that Tibetans were prepared to treasure, despite what seemed to European printers - used to recycling movable type - their inconvenient bulk.

This now brings us back to paper, and its Buddhist role in the dissemination of meaningful pattern in the form of images and texts. It has recently been established that a stamp on paper bearing both a Buddha image and text (in Sanskrit) dates to about the end of the fifth century (Barrett 2008, 67). Within about a century or so this technique had become common enough for Daoists 
to list it as a legitimate form of image creation also (Barrett 1997). ${ }^{9}$ But though we do hear of a few large seals with outsize messages from quite early on, they must have been distinctly inconvenient to use, whereas the multiple Buddha stampings that survive from Dunhuang are all quite small..$^{10}$ Rubbing was certainly used in the seventh century to convey a facsimile likeness of a Buddha relic from India to China, and thence via recreations there to Japan in more than one copy. Interestingly for the history of printing, and indeed for the history of the conception of 'relic' in China, this was the imprint of the Buddha's feet. ${ }^{11}$ For Buddhists, perhaps, few patterns could be more meaningful, though in China the Buddha's handprints were to be discerned on the landscape as well (see Robson 2012, 92). By contrast, the same cult of the footprint is said to have spread from Sri Lanka to Thailand in the fourteenth century simply by freehand copying (Raben and Dhiravat na Pombejra 1997, 82). In this case the faithful reproduction of a pre-existing impression, and perhaps the transfer of sanctity by contact with a sacred object, made the use of a rubbing an obvious choice, but for reproducing in bulk larger images or portions of text the technique would have been at a disadvantage not so much because it was slow (scribal copying, though capable of stenographic speed, was usually conducted at quite a measured pace which any technology would find quite easy to outperform) but because it was a method of pattern transfer quite prodigal in its expenditure of ink.

Under what circumstances did someone hit upon the hybrid technique of bringing the paper to the stamp, as to a surface to be rubbed? My own hypothesis, based on the rapid spread of this technology through East Asia in contexts closely associated with royalty, is that it was used to create many copies of Buddhist texts that might serve as relics for widespread distribution, in emulation of the legendary feat of Ashoka in distributing the Buddha's relics (this hypothesis is outlined in Barrett 2008). Yet in Tang China this practice of relic distribution was firmly associated with dynastic rivals - with the preceding Sui dynasty, and especially with the usurper, Emperor/Empress Wu, who may in

9 I now date the source to the Sui period on the basis of the indication in the text of institutions unique to the Sui mentioned by Verellen $(1994,122)$ : my thanks to Antonello Palumbo for pointing this out.

10 Best known of these longer yet still only four-inch (square?) stamps, carrying 120 characters, was that for use on clay against aquatic monsters in the early fourth century $\mathrm{CE}$, though it is possible that seals bearing a Buddhist message 210 characters long were made in the seventh century: cf. Carter 1955, 13; Barrett 2011, 204-5.

11 For the relationship of this specific relic to a wider Chinese context, see Barrett 1990, 102; for the Buddhist cult, see Strong 2004, 85-97. For some notes on the retrieval of a facsimile from India and its transmission to Japan, see Ono Katsutoshi 1967, 113-14. 
my estimation have used printed relics. As a result the dynasty itself avoided employing printing, though where multiple copies were needed in a short space of time - as in the production of calendars - they did nothing to stop the spread of the new technology as such. ${ }^{12}$

It was, then, these short printed spells, dhäranī, that Younghusband's invaders found serving as small, empowering elements of Buddha presence within statues. Little do they seem to have appreciated that to those whom they despoiled, these apparently valueless scraps of paper were veritable relics of the Buddha himself. Yet this may not be quite the status of the print in the Pelliot Tibetan collection. Eugene Wang, drawing in part on the research of Paul Copp, the leading authority on dhärañ̄ in Tang China, points out that not all such texts associated with relic deposits can actually be understood as relics. In the Chinese environment, by the tenth century at least, Daoist ideas of talismanic writing had apparently bestowed upon these written relics a value of their own, especially perhaps in the minds of laypersons unconnected with the rhetoric of managing the Buddha's residual presence. They became, in short, protective charms (Wang 2011, especially p. 159). One good indication of this is the degree to which they were carried about the person inside armbands or otherwise left in burials, after serving as phylacteries. Katherine R. Tsiang has described a number of these, plus a couple of related manuscript examples, that have been retrieved by archaeologists in recent years (Tsiang 2010, 224-38). But although her broader treatment of early Buddhist printed materials is extensive, she does not touch upon Pelliot's Tibetan printed text. No doubt this print requires further examination within the context that she provides, but this would go substantially beyond the aim of these remarks.

For, to repeat, rather than introduce new evidence, the aim here has been to sketch in lightly the full range of what we already know. And what we know is that the printed book did not spring into being fully formed like Athena from the head of Zeus, though in Buddhist China the step from single sheet to multipage book was no doubt eased by the fact that all Buddha's word, even the most prolix texts, constituted Buddha relics. It is true that the paths taken in Europe and East Asia differed substantially in the exact technologies that came to be preferred, even if some degree of East-West influence through the Islamic world could have provided some early stimulus (Elverskog 2010, 104-15, which also provides good illustrated examples in Tibetan, Mongol and Arabic of the materials discussed). This is very effectively illustrated by the way in which the

12 The evidence for this is outlined in Barrett 2012. I hope in due course to publish an expanded version of this study making clear how its findings are consistent with the hypothesis put forward in my earlier work. 
rather detailed but not absolutely explicit account of the block printing of paper money in the Mongol empire given by Marco Polo is depicted by European artists of the early sixteenth century: they can only imagine that dies were used to stamp the seal of the Great Khan onto the money (see Vogel 2013, 125). For we know that the system initiated but probably not perfected by Gutenberg was something very much more complex than anything considered here. But there is a substantial background, a 'prehistory' to it strictly within Europe, based on this time honoured method for the transfer of linguistically meaningful pattern. How important this may have been is as yet a little difficult to discern, and of course this may impinge to some extent on the degree to which we may one day continue to see the rise of the post-Gutenberg technology as truly revolutionary, though the major changes that it ushered in can hardly be ignored. The prehistory to this, however, may have started in Lydia long ago as a form of stamping soft metal with hard metal, but it was clearly also used to transfer writing from other hard to soft surfaces long before Gutenberg's time. The use of the alphabet on stamps or metal punches, as demonstrated for example by the altarpiece of Pellegrinus II at Cividale, Friuli, round about $1200 \mathrm{CE}$, must for example surely have to be taken into account - even if the claim that this exhibits the earliest example of a product of movable type may in itself not be sustainable (Lipinsky 1986). Punches indeed have a history in the Eastern Mediterranean dating back about three and a half thousand years, if one takes into account the Phaistos Disc (Godart 1995, 113-14). Block printing, for that matter, has an Eastern Mediterranean history of about two and a half thousand years, if one includes the block printed amulet now housed in the Schøyen Collection, Ms $5236 .{ }^{13}$ Both these cases, however, involved the use of gold, either for what can apparently only have been golden punches or for the gold leaf surface impressed to make the amulet. Obviously, then, economically viable mass printing on any scale had to await the bringing together in East Asia of wood and paper.

But again, to go into a full account of that would take us too far. In sum, however, we can simply say that both in East and West the concept of pattern transfer was very widely known and understood - and very multifariously put into practice. When H. G. Wells said that printing was "the most obvious of inventions", already present in the use of seals, this may rather slight the technological advances required, but actually he underestimates the prehistory even to that development (Wells 1965, 50, 207). By highlighting a range of simpler technologies, however, I merely wish to draw attention to two points. One I have

13 www.schoyencollection.com/pre1450.html \#5236, accessed 28 April, 2014. The same website shows examples of Sumerian block printing on clay more than four thousand years old. 
made before, namely that a history of technology on its own does not explain everything - whatever the materials used, in China at any rate religious ideology seems to be very important too. The other is a yet more resounding truism, but one still perhaps worth enunciating: that in any revolution, many things will still remain the same. The crucial issue from which we started, namely where we draw our base line, and hence what we consider revolutionary, is therefore not necessarily a self-evident matter.

\section{References}

Aubin, Françoise. 2010. “To Impress the Seal: A Technological Transfer." In Representing Power in Ancient Inner Asia: Legitimacy, Transmission and the Sacred, edited by Isabelle Charleux, Grégory Delaplace, Roberte Hamayon, and Scott Pearce, 159-207. Bellingham, wA: Western Washington University.

Barrett, T. H. 1990. "Exploratory observations on some weeping pilgrims." In The Buddhist Forum, edited by T. Skorupski, 99-110. London: SOAS.

1997. "The Feng-tao k'o and printing on paper in seventh-century China." Bulletin of the School of Oriental and African Studies 6o(3): 538-40. 2001. "Woodblock dyeing and printing technology in China, c.700 AD: the innovations of Ms. Liu, and other evidence." Bulletin of the School of Oriental and African Studies 64(2): 240-47. 2005. "The Religious Meaning of Buddhist Sculpture in its Cultural Setting: The

Buddha Images of Qingzhou in the Light of Recent Scholarship." Buddhist Studies Review 22.1: 44-69. 2008. The Woman Who Discovered Printing. London and New Haven: Yale University Press.

2011. "The Woman Who Invented Notepaper: Towards a Comparative Historiography of Paper and Print." Journal of the Royal Asiatic Society Series 3, 21(2): 199-210.

2012. "On the Road to China: The Continental Relocation of Sacred Space and its Consequences for Mountains, Minds, and Texts." In Images, Relics, and Legends: The Formation and Transformation of Buddhist Sacred Sites (Essays in Honor of Koichi Shinohara), edited by James Benn, Jinhua Chen, and James Robson, 46-67. Oakville, Ontario: Mosaic Press.

2012. From Religious Ideology to Political Expediency in Early Printing London: Minnow Press.

- www.sms.cam.ac.uk/media/1259713 - video of unpublished paper, Cambridge, May 29, 2012; accessed 28 April 2014.

Beal, Samuel. 1911. The Life of Hiuen-tsiang. London; Kegan, Paul, Trench, Trübner. 
Boretti, Valentina. 2004. "The quasi-genderless heresy: the Dhūtaists and Master Jizhao." Bulletin of the School of Oriental and African Studies 67(3):349-68.

Burke, Peter. 1964. The Renaissance. London: Longmans.

Čapek, Abe. 1962. Chinese Stone-Pictures. London: Spring Books.

Carter, Thomas Francis. 1955. (Revised by L. Carrington Goodrich.) The Invention of Printing in China and Its Spread Westward. New York: The Ronald Press Company.

Cohen, Monique and Nathalie Monnet. 1992. Impressions de Chine. Paris: Bibliothèque Nationale.

Drexler, Monika. 1994. Daoistische Schriftmagie. Stuttgart: Steiner.

Elverskog, Johan. 2010. Buddhism and Islam on the Silk Road. Philadelphia, PA: University of Pennsylvania Press.

Fraser, Sarah E. 2004. Performing the Visual: The Practice of Buddhist Wall Painting in China and Central Asia, 618-96o. Stanford, cA: Stanford University Press.

French, Patrick. 1994. Younghusband: The Last Great Imperial Adventurer. London: HarperCollins.

Godart, Louis. 1995. The Phaistos Disc: The Enigma of an Aegean Script. Athens: Itanos Publications.

Goody, Jack. 2010. Renaissance: The One or the Many? Cambridge: Cambridge University Press.

Hansen, Valerie. 2011. "Review of Asaph Goldschmidt, The Evolution of Chinese Medicine: Song Dynasty, 960-120o." East Asian Science, Technology, and Medicine 14: 219-21.

Ledderose, Lothar. 2000. Ten Thousand Things: Module and Mass Production in Chinese Art. Princeton, NJ: Princeton University Press.

Lin, James C. S., ed. 2012. The Search for Immortality. New Haven, CT, and London: Yale University Press.

Lipinsky, Angelo. 1986. "La pala argentina del patriarca Pellegrino nella collegiate di Cividale e le sue iscrizioni con caratteri mobile." Ateneo Veneto 24(1-2): 75-80.

Liu Wing-fong. 1986. Traditional Chinese Rubbing Techniques. Hong Kong: Hong Kong Urban Council.

McDermott, Joseph P. 2006. A Social History of the Chinese Book: Books and Literati in Culture in Late Imperial China. Hong Kong: Hong Kong University Press.

McGonagall, William. 1934. Poetic Gems. London: Gerald Duckworth/Dundee: David Winter \& Son.

Migot, André. 1956. Tibetan Marches. London: Rupert Hart-Davis.

Nicholls, Richard. 1978. Greek Gods and Goddesses in Miniature. (Fitzwilliam Museum exhibition catalogue.) Stevenage: Publications for Companies.

Ono Katsutoshi 小野勝年. 1967. Nittō guhō junrei kōki no kenkyū 入蓎求法巡禮行記 の研. Tokyo: Suzuki gakujutsu zaidan.

Parshall, Peter and Rainer Schoch. 2005. Origins of European Printmaking. New Haven, Ст and London: Yale University Press. 
Perry, Grayson. 2011. The Tomb of the Unknown Craftsman. London: British Museum Press.

Raben, Remco and Dhiravat na Pombejra. 1997. In the King's Trail: An 18th Century Dutch Journey to the Buddha's Footprint. Bangkok: The Royal Netherlands Embassy.

Richter, Antje. 2013. Letters and Epistolary Culture in Early Medieval China. Seattle, WA: University of Washington Press.

Robson, James. 2012. "Changing Places: The Conversion of Religious Sites in China." In Images, Relics, and Legends: The Formation and Transformation of Buddhist Sacred Sites (Essays in Honor of Koichi Shinohara), edited by James Benn, Jinhua Chen, and James Robson, 90-111. Oakville, Ontario: Mosaic Press.

Roerich, George. 1949. The Blue Annals. Calcutta; Royal Asiatic Society of Bengal.

Rong Xinjiang. 2004. "Official Life at Dunhuang in the Tenth Century." In The Silk Road: Trade, Travel, War and Faith, edited by Susan Whitfield, 57-62. London: The British Library.

van Schaik, Sam, and Imre Galambos. 2012. Manuscripts and Travellers: The SinoTibetan Documents of a Tenth-century Buddhist Pilgrim. Berlin: de Gruyter.

Starr, Kenneth. 2008. Black Tigers: A Grammar of Chinese Rubbings. Seattle, wA, and London: University of Washington Press.

Strong, John S. 2004. Relics of the Buddha. Princeton, NJ: Princeton University Press.

Tsiang, Katherine R. 2010. "Buddhist Printed Images and Texts of the Eighth-Tenth Centuries: Typologies of Replication and Representation.” In Esoteric Buddhism at Dunhuang: Rites and Teachings for This Life and Beyond. Edited by Matthew T. Kapstein and Sam van Schaik, 201-52. Leiden and Boston, MA: Brill.

Tsien Tsuin-hsuin. 1985. Science and Civilisation in China, Volume v.1. Cambridge: Cambridge University Press.

Van Gulik, Robert H. 1958. Chinese Pictorial Art as Viewed by the Connoisseur. Rome: ISMEO.

Verellen, Franciscus. 1994. "A Forgotten T'ang Restoration: The Taoist Dispensation after Huang Ch'ao." Asia Major 3rd series 7(1): 107-53.

Vogel, Hans Ulrich. 2013. Marco Polo Was in China. Leiden and Boston, MA: Brill.

Wang, Eugene. 2011. "Ritual Practice Without a Practitioner? Early Eleventh Century dhāran̄ī Prints in the Ruigangsi Pagoda." Cahiers d'Extrême-Asie 20: 127-6o.

Wang, Yugen. 2011. Ten Thousand Scrolls: Reading and Writing in the Poetics of Huang Tingjian and the Late Northern Song. Cambridge, MA: Harvard University Press.

Wells, H. G. 1965 [1922]. A Short History of the World. Harmondsworth: Penguin.

Williams, Paul. 2009. Mahāyāna Buddhism: The Doctrinal Foundations. (Second edition.) Abingdon: Routledge. 